\title{
LITERATUROZNAWSTWO
}

Anna Alsztyniuk

DOI $10.15290 /$ sw.2020.20.01

Uniwersytet w Białymstoku

Wydział Filologiczny

Katedra Badań Filologicznych „Wschód-Zachód”

tel.: +48 857457512

e-mail: a.alsztyniuk@uwb.edu.pl

ORCID ID: https://orcid.org/0000-0002-6013-2430

\section{Антиутопические произведения Евгения Замятина и Василя Гигевича: к проблеме сходства и различий}

Ключевые слова: антиутопия, роман $\mathrm{Mbl}$, повесть Марсиянское путешествие, предупреждение

Двадцатый век вошел уже в историю как время научных открытий и трагических событий: мировых войн, революций, разгула терроризма. Все это, несомненно, нашло отражение в литературе, в частности, в дискредитации утопии и появлении ряда произведений, сосредоточенных на пессимистическом, катастрофическом видении будущего. Писатели создают произведения, в которых или наиболее полно раскрываются угрозы, которые несут человеческому существованию некоторые идеологии и политические режимы, или представляют конец человечества в результате машинного господства либо вторжения иноземных цивилизаций. Разумеется, такое содержание для своего выражения требует особого жанрового решения. Следует согласиться со мнением польского исследователя Дариуша Войтчака о том, что самое серьезное предупреждение о будущем содержится в жанре антиутопии:

Antyutopia (...) oferuje całkiem nową, infernalną wizję zdegenerowanego życia, za które odpowiedzialny jest wyłącznie sam człowiek, oferuje jakże bezpośrednią i prawdopodobną - w kontekście faszystowskich i bolszewickich doświadczeń naszego wieku - wizję szczególnego końca cywilizacji, rozumianego jako całkowita likwidacja odrębności jednostek. (...) 
Antyutopia byłaby więc wizją piekła społecznego najwyższego rzędu - piekła nieodwracalnego, bo osiągnięcie ideału jednorodności społeczeństwa (najczęściej poprzez terror i propagandę) przekreśla możliwość powrotu do stanu poprzedniego, gdyż wtedy nie ma już nikogo, kto takie pragnienia mógłby odczuwać [Wojtczak 1994, 10].

Антиутопия, в отличие от утопии, представляет идеальную модель мира иллюзией и обнаруживает пагубные и непредвиденные последствия научно-технического прогресса. Таким образом антиутопией можно считать:

1) произведение, направленное против конкретной модели утопического государства, представленное автором утопии в его книге;

2) произведение, направленное против уже существующей или продвигаемой государственной системы, которая должна была стать раем на земле, но, по мнению антиутописта, угрожает благу человека;

3) произведения с предупреждением о воздействии политических, социальных, экономических, технологических и культурных тенденций, которые могут наблюдаться в действительности вместе или отдельно и, по мнению автора, угрожают человеку как личности и коллективу [Słownik 2012, 39-40].

В антиутопическом произведении автор сосредоточен на изображении сути негативного воздействия какой-либо власти на личность, что, несомненно, влияет на особенности этого литературного жанра:

Antyutopia - gatunek literacki, który (...) prezentuje negatywne wizje społeczeństwa przyszłości; powstał w wyniku strukturalnego splotu kilku gatunków: utopii, powieści społecznej, science fiction i powieści detektywistycznej. W utworach należących do tego gatunku główną rolę pełni rozwój psychiczny postaci bohatera i akcja o wyraźnie schematycznym przebiegu i negatywnym rozwiązaniu; narracja typowa dla powieści psychologicznej [Wojtczak 1994, 41].

Современные исследования жанра антиутопии ${ }^{1}$ свидетельствуют об отсутствии четкого определения этого литературного жанра. Ряд

1 Об анитиутопии писали: А. Ю. Смирнов, 2005, Антиутопия в парадигме современного литературоведения, "Веснік БДУ", сер. 4, № 3, с. 32-36; А. Ю. Смирнов, 2009, Литературная антиутопия: проблемя генезиса, "Веснік БДУ", сер. 4, № 1, с. 39-43; Д. І.-Т. Дудзінская, 2009, Да праблемы жанру антыутопіi ў беларускай літаратуры, [у:] Вылуัленча-мастачкія, арганізачьйныя $i$ ідэалагічныля праблемы сучаснай беларускай літаратуры ў яе сувязях з грамадскімі практыкамі. Матэрыяль Рэспубліканскай навукова-тэарэтычнай канфкрэниыі (Мінск, 19-20 мая 2009 года, Мінск; Б. Ланин, 2011, Наследие Евгения Замятина и современная русская антиутоnия, "Acta Slavica Iaponica", т. 29, с. 49-63; И. Извекова, Антиутопия: перспекивь 
литературоведов дает свое собственное определение жанра, который возник как отрицание принципов утопии. В связи с этим в критической литературе параллельно с антиутопией используются понятия квазиутопия, дистопия, какотопия, постантиутопия, негативная утопия, черная утопия и другие.

Роман Mbl Евгения Замятина (1884-1937) - знаковое явление в литературе XX века, одно из первых произведений в жанре антиутопии. Он был написан в 1920-1921 годах и впервые опубликован на английском языке в 1924 г. в Нью-Йорке, на русском - там же в 1952 г. В России роман увидел свет лишь в 1988 г. в журнале "Знамя". При том в русской литературе в 20-30-ые годы XX века появляются произведения, в которых присутствует антиутопическое начало: Ompыъвок будущего романа (Написано по речепту “Алой чумь”") Аркадия Аверченко, Город правды Льва Лунца, Рассказ аб Аке и человечестве (1919) Ефима Зозули, Дьяволиада (1923), Роковье яйца (1924) и Собачье сердце (1925) Михаила Булгакова, Ленинград (1925) Михаила Козырева, Город Градов (1927) и Чевенгур (1926-1928) Андрея Платонова и другие. Надо подчеркнуть, что вслед за $M b l$ Е. Замятина пишутся произведения О дивный новылй мир (1931) Олдоса Хаксли и 1984 (1948) Джорджа Оруэла.

Белорусская антиутопия нашла свое обоснование прежде всего в исследованиях Василия Журавлева, Галины Нефагиной, Таисии Сухоцкой, которые раздлядалі антыутапічныл творы з пункту гледжання ix адпаведнасиі паэтыци антыутопій, ужо сцвержаных у сусветнай літаратурь [Дудзінская 2009, 91]. Иную точку зрения представляет Дина Дудинская, которая считает, что існуе значная адрознасиь паміж уласнабеларускімі паэталагічнымі пошукамі ў жанры антылтоnii $i$ - пошукамі сусветнай літаратурь [Дудзінская 2009, 94]. Примерами белорусской антиутопии класического типа признано считать прежде всего произведения Андрея Макаенка, Алеся Адамовича, Янки Сипакова, Василя Гигевича и других. Преимущественно этот жанр реализует себя в белорусской литературе в рамках социальной фантастики, а его жанровая чистота - редкое явление [Голубович, online].

Всему творчеству Гигевича (год рождения 1947) характерно углубление в проблему узаемаадносін чалавека $i$ часу, чалавека $i$ абставін,

развития и трансформачии жанра в современной литературе, [online], http://ea. donntu.org:8080/jspui/bitstream/123456789/31916/1/Izvyekova201604.pdf, [15.11.2019]; Н. А. Хафизова, 2017, Антиутопия и ужасное как тень культурь, "Вестник ПНИПУ. Культура. История. Философия. Право", № 4, с. 82-89. 
чалавека ў яго прыроднай зямной сутнасиі $і$ абставін навукова-тэхнакратычнай, глабалізаванай на сённяшні дзень иьвілізачыі [Андраюк 2015, 830]. В первый период творческого пути Гигевича особенно волнуют вопросы деревенской жизни, взаимоотношений молодого человека с обстоятельствами повседневной жизни. После Чернобыльской катастрофы авторское внимание было переключено на научные проблемы. Тогда и возникли его роман Карабель (1989), повести Марсіянскае падарожжа (1990), Палтэргейст (1991), Пабакі (1993), роман Кентаўры (1993). Во всех упомянутых выше произведениях можно найти либо черты антиутопии, либо отдельные элементы этого жанра. В первом своем фантастическом романе Kapaбель (1988) писатель воссоздает модель замятиновского романа [Смирнов, 2005], метафорически разоблачает коммунистическую идеологию [Голубович, online]. Наше внимание привлекла ставшая важным шагом в творческой эволюции Гигевича повесть Марсіянскае падарожжа, в которой нашло выражение новаторство писателя: ён адыходзіџь ад традыцыйнай рэалістьчнай манерь пісьма $і$ набліжаеича да мадэрністычнага дыскурсу [Тычко 2010, online]. Писатель ориентируется на традиционные жанровые каноны антиутопии, но при том обогащает повесть, между прочим, за счет жанрово-стилистической разнородности текста (в дневнике героя находим фрагменты стенограммы научной конференции). Композиционная фрагментарность является одной из главных черт повести Пабакі (1993), которая считается закономерным этапом литературной эволюции белорусской антиутопии [Голубович, online].

В антиутопии писатели обычно изображают и анализируют гипотетическую структуру антиобщества, при чем основой для прогностических авторских изображений делают страхи и надежды эпохи, в которой писатель существует [Извекова, online]. Замятин пишет свой роман в эпицентре превращений XX века: Военный коммунизм, послевоенная разруха, пролеткультовские идеи техницизма и коллективизма, воспоминания автора о машинизированной Англии, где до революиии он строил ледоколь, - все это стало основой для создания странного фантастического мира Единого Государства [Жданов, online]. Появление замятинского $M b$ после взлета революционных утопий, представляющих спасительный машинный мир, имеет глубокий смысл. Писатель подчеркивает, что развитие наук и технологий влияет на человека, его эволюцию, изменяет его природу и систему его ценностей, потому что личность трансформируется в придаток машинь, превращается в механизм [Денисов, Денисова 2017, 20]. 
Обращение Гигевича (по профессии физика и журналиста) к научной фантастике также было продиктовано раздумием над ролью современной науки в общественном развитии и поэтому писатель з $а д$ наго боку, імкнециа паказаць неабмежаванья навукова-тэхнічныля магчьмасиі сучаснага чалавечага грамадства ў заваяванні сусвету, у асваенні касмічнай прасторь, з другога - да спасціження чалавечага, наогул жьвога арганізма, удасканалення яго прыроды [Андраюк 2015, 833]. Непосредственным же толчком для создания повести Марсіянскае падарожжа стало, очевидно, реальное событие, о котором вспоминается на первых страницах произведения. Автор ссылается на трагедию, котороя произошла 18 ноября 1978 г. в Гвиане. В этот день погибло 913 человек, совершивших по приказу главы организации "Храм народов" Джима Джонса т. н. "революционное самоубийство". Во время следствия выяснилось, что Джонс был очарован романом 1984 Д. Оруэла и реализовал оруэловское видение общества в своей секте. По-видимому, Гигевич решил показать читателю опасность слепого подчинения идеям, что было важно в то время также из-за общей ситуации в мире. Ведь повесть Марсіянскае падарожжа была написана во время событий, которые вызывали расстерянность и пессимистические настроения.

Итак, можно сказать, что произведения Замятина и Гигевича являются результатом тревоги писателей за будущее человечества, вступившего, по их мнению, на тупиковый путь, по которому движется современная цивилизация. Тематика и проблематика романа $M b$ и повести Марсіянскае падарожжа имеют обобщенный, универсальный характер. Поэтому Замятин точно не определяет место, в котором происходят представленные им события, а Гигевич отправляет своих героев в неизведанное космическое пространство. Произведения Замятина и Гигевича написаны в форме дневника, что концентрирует внимание читателя на главном персонаже. При том записи героев показывают повседневную жизнь общества, чем и обличают ее: $B$ действительности же, помимо самовьражения, она имеет своей иелью предупредить, известить, обратить внимание, проинформировать, словом, донести читателю информацию о возможной эволючии современного общественного устройства [Ланин, online].

Жители Единого Государства из романа Замятина находятся под абсолютной властью Благодетеля. Собственное имя единого человека, у которого оно вообще есть, обозначается с помощью функции, которую он выполняет в государстве, и ассоциируется с положительными чертами. Сам Благодетель является объектом поклонения, считается 
своего рода альфой и омегой. То, как он выглядит в изображенном мире, продиктовано мотивацией писателя, который показывает, с одной стороны - сверхчеловечество героя, с другой - его бесчеловечность:

А наверху, на Кубе, возле Машины - неподвижная, как из металла, фигура того, кого мы именуем Благодетелем. Лица отсюда, снизу, не разобрать: видно только, что оно ограничено строгими, величественными, квадратными очертаниями. Но зато руки... Так иногда бывает на фотографических снимках: слишком близко, на первом плане, поставленные руки - выходят огромными, приковывают взор - заслоняют собою все. Эти тяжкие, пока еще спокойно лежащие на коленях руки - ясно: они каменные, и колени - еле выдерживают их вес... [Замятин 2011, 35-36].

Неслучайно Замятин сосредоточен на руках Благодателя: один его жест решает о жизни и смерти человека:

Неизмеримая секунда. Рука, включая ток, опустилась. Сверкнуло нестерпимо острое лезвие луча - как дрожь, еле слышный треск в трубках Машины. Распростертое тело - все в легкой, светящейся дымке - и вот в глазах тает, тает, растворяется с ужасающей быстротой. И - ничего: только лужа химически чистой воды, еще минуту назад буйно и красно бившая сердце... [Замятин 2011, 37].

Публичная смертная казнь человека, деятельность которого не соответствовала идеям Единого Государства, происходит в день государственного праздника в присутствии всех нумеров. Таким образом Благодатель предупреждает, что "преступник" всегда будет найден и наказан.

Надо отметить, что Благодатель ежегодно выбирается по единогласию граждан. Никто не пытается выступить против власти тирана, хотя бы став его контркандидатом:

Нужно ли говорить, что у нас и здесь, как во всем - ни для каких случайностей нет места, никаких неожиданностей быть не может. И самые выборы имеют значение скорее символическое: напомнить, что мы единый, могучий миллионноклеточный организм, что мы - говоря словами Евангелия древних - единая Церковь. Потому, что история Единого Государства не знает случая, чтобы в этот торжественный день хотя бы один голос осмелился нарушить величественный унисон [Замятин 2011, 101].

Очевидно, достаточно адекватно определил природу общественного устройства в романе $M$ ль Лев Наврозов в статье Замятин и Оруэлл: $2 x 2=4 ?:$ 
Общество, которое изображает Замятин, основано на «разуме», то есть на том, что для 99 процентов взрослого населения ясно, как $2 \times 2=4$. Это общество не навязано никаким тираном-злодеем. Его создали «Мы», 99 процентов населения, их «разум», как следствие развития науки, техники и медицины при отсутствии гениальности вне их. Никакого отношения к советской России 1920 года это Единое Государство не имеет, кроме того, что советская Россия тоже вступила в 1917 году на западный путь «разума» [Наврозов, online].

Власть в современном виде для главного героя Д-503 была установлена тысячу лет тому и является следствием Двухсотлетней Войны войны между городом и деревней. Научно-технический прогресс имел свои социально-экологические последствия: натуральную пищу заменила нефтяная, в результате чего выжило только 0,2 земного населения. Отвергнув образ жизни предков, люди почувствовали себя счастливыми. После окончания войны они забыли о глобальных проблемах: социальном неравенстве, безработице, нищете. Видимого счастья было достаточно, чтобы поверить, что система полного подчинения одной личности - это почти реальный земной рай. На этом, следовательно, эволюция правил человеческой жизни не закончилась:

Естественно, что подчинив себе Голод (алгебраический = сумме внешних благ), Единое Государство повело наступление против другого владыки мира - против Любви. Наконец, и эта стихия была тоже побеждена, т. е. организована, математизирована, и около 300 лет назад был провозглашен наш исторический "Lex sexualis": "всякий из нумеров имеет право как на сексуальный продукт - на любой нумер” [Замятин 2011, 18].

Постепенно реформы охватили все сферы деятельности человека и лишили его прав на свободу и личную неприкосновенность, оставив ему лишь внешнюю оболочку обезличенного человеческого существа.

В повести Гигевича действительность также была создана коллективом самих марсиянских путешественников, которые решили вести жизнь под контролем Большого Компьютера. Писатель обращает внимание на причины, повлиявшие на решение покинуть Землю навсегда:

Катастрафічна хутка расло беспрацоўе, трывогу выклікала наркаманія сярод падлеткаў і моладзі, недавер і падазронасць да бліжняга адасоблівалі людзей, змушалі кожную сям'ю трымаць у кватэры зброю і сабак; (...) Расла колькасць веруючых у розныя містычныя вучэнні. Усё гэта лавінаю навальвалася на людзей, i, чым мацней дыктары тэлебачання і кіраўнікі краіны лямантавалі аб прагрэсе, свабодзе, раўнапраўі, пагрозе з Усходу, тым мацней простыя людзі адчувалі трывогу і разгубленасць [Гігевіч 1990, 173-174]. 
Гигевич перечисляет также другие факторы, ускорившие это решение: нарастающий конфликт поколений, кризис нравственно-христианских ценностей, слухи о неизбежном конце света, катаклизмы. Усталость и разочарование в повседневной жизни привели к тому, что, несмотря ни на что, измученные жизненными обстоятельствами герои захотели забыть о них навсегда. Они поверили доктору кибернетики Милеру и подчинились механизму селекции, уверовав, что только они, избранные, смогут создать счастливое общество на Марсе. Никто не думал о цене, которую придется за это заплатить: $Y$ той час (...) пра штучны розум людзі думалі меней за ўсё, ды $i$, калі разабрачца, так яно $і$ павінна было быць: якая розніча простаму чалавеку, хто ім будзе кіравачь: прэзідэнт, парламент иі халодная машьна... [Гігевіч 1990, 176].

Инициатор экспедиции - Милер - во многом напоминает замятинского Благодетеля: нечым нагадваў машыну, сапраўдную дакладную кібернетычную машыну, якая ў сваёй рабоче не ведае збояў $і$ сумненняў [Гігевіч 1990, 169]. Он не прерывает процесс казни Степана Коренева, который пытался перостроить программу работы Большого Компьютера и возвратиться на Землю. По своему представлению Милер делает то, что нужно для поддержания "счастья" колонизаторов:

Скажыце мне, у чым я вінаваты? Можа, у тым, што стварыў Вялікі Камп'ютэр, які дапамагае нам жыць у космасе? (...) Вы можаце спакойна жыць... Я вам гэта гарантаваў?.. I, як самі бачыце, я гэта выконваю, кожны з вас цяпер мае бясплатную ежу і жыллё; калі будзем выконваць загады штучнага розуму, то гэткім жа спакойным будзе наша жыццё і на Марсе [Гігевіч 1990, 211-212].

Со временем жители Марса догадались, что цель эксперимента Милера - попытка властвовать над людьми, а сам конструктор Большого Компьютера хотел через некоторое время покинуть колонизаторов и возвратиться в земной мир.

Одной из основных характеристик мира, представленного как Замятиным, так и Гигевичем, является его замкнутость. Стеклянный рай Единственного Государства был отделен от остального мира Зеленой Стеною. Еще большее расстояние отделяло марсианских колонизаторов от Земли. Все это вскоре оказало отрезвляющее влияние на ситуацию, в которой оказались персонажи рассматриваемых произведений. Как пишет Светлана Шишкина:

Замкнутость пространства, его небольшие размеры и отсюда «просматриваемость» каждого движения лишают героя возможности что-то 
изменить в системе. Оно - пространство - отталкивает личность, деперсонифицирует ее, выхолащивая человеческое, пробуждая звериные инстинкты послушания, подчинения, ибо только это ведет к физическому самосохранению. Дискурс антиутопии наполнен насилием. «Безумие разума» здесь наглядно и объемно [Шишкина, online].

В романе $M b l$ Замятин, проецируя свое время с основными его тенденциями и направлениями развития, показывает страну далекого будущего, в котором человек становится цифрой и подчинен полному контролю. Власть Единого Государства обеспечивает его граждан материально (они не должны заботиться о еде, одежде, у них есть свои квартиры), но оно отбирает у них не только имя и фамилию, а значит личность, но и основные права человека, прежде всего - волю и свободу, превращая людей в номера, каждая минута существования которых распланирована сверху:

Каждое утро, с шестиколесной точностью, в один и тот же час и в одну и ту же минуту - мы, миллионы, встаем как один. В один и тот же час, единомиллионно, начинаем работу - единомиллионно кончаем. И сливаясь в единое, миллионнорукое тело, в одну и ту же, назначенную Скрижалью, секунду - мы подносим ложки ко рту и в одну и ту же секунду выходим на прогулку и идем в аудитории, в зал Тэйлоровских экзерсисов, отходим ко сну... [Замятин 2011, 11].

Единственное в какой-то мере свободное время - два часа в день, называемые Личными Часами. Тогда граждане маршируют по аллеям, пишут произведения в честь своего государства, используют розовый билет, который дает право проводить время наедине с другим “сексуальным продуктом". Власть все решает также о детях, не имеющих возможности воспитываться в семьях, которых в государстве и нет. Для поддержания порядка существует аппарат безопасности: контролем над обществом занимаются Хранители, при том каждый гражданин может стать доносчиком, а мембраньл, изящно задекорированнье, на всех проспектах записььвают для Бюро Хранителей уличнье разговорьл [Замятин 2011, 41].

В свою очередь и Гигевич в повести Марсіянскае падарожжа рассказывает о необычных аспектах влияния научно-технического прогресса на судьбу человечества. Писатель показывает жизнь общества под управлением искусственного интеллекта. Сначала колонизаторы ведут земной образ жизни, но с каждым днем он становится неузнаваемым. Они работают для своего государства, так как оно обеспечивает их материально, но в свободное время каждый должен про- 
слушать цикл лекций по философии нового космического мышления и лекции заканчиваются экзаменом: Tbıx жа, хто дрэнна здаваў ix альбо не хацеў слухаць лекиьі, абмяжоўвалі ў ежь $i$ ў вольным чаce... [Гігевіч 1990, 197]. После лекций люди торопятся да відэаэкранаў, дзе не трэба думаць $i$ можна атрылліваць фізічную асалоду [Гігевіч 1990, 202]. Благодаря же браслетам Большой Компьютер не только следит за жителями, подслушивает их, но и влияет на их поведение, самочувствие: Я заўважьй, што тады, як пачьнаю з кімсьиі гаварыць пра недасканаласць штучнага розуму, у мяне адразу ж пачьнае балеиь галава [Гігевіч 1990, 201].

Тип главного героя антиутопических произведений можно условно обозначить как Ното scribens (Давшан) - человек пишущий [Смирнов 2005, 35], которому текст дает возможность выразить протест. Повествование от первого лица позволяет также более глубоко проникнуть в мысли и чувства героя, определить причины принимаемых им решений, понять особенности мировосприятия. Записки главных героев являются свидетельством их психической эволюции и одновременно помогают углубить знания об истинной природе мира, в котором герой живет.

Главный герой романа $M$ ьь Д-503 - строитель Интеграла, математик, проявляющий слепое поклонение утопическому миру Единственного Государства. Он начинает писать в связи с указом власти, ожидающей, что каждый способный к писательской деятельности гражданин должен прославлять государство. Со временем заметки героя преображаются в записи его сомнений, подтверждают рождение воображения, души, что является признаком запретного индивидуализма [Wojtczak 1994, 75].

Герой Гигевича, обращаясь к дневниковым записям, руководствуется совершенно другими причинами:

З учарашняга дня у галаве маёй б'ецца адно і тое ж, адно і тое ж: "Усё мае пачатак, усё мае канец..." Неяк само па сабе яно паяўляецца у мяне, і мо таму, каб найхутчэй пазбавіцца ад гэтых слоў, я сеў да пісьмовага стала надта і не задумваючыся, ці будуць калісьці глядзець чыесьці вочы на спісаныя мною лісткі паперы [Гігевіч 1990, 156].

Предчувствуя смерть, журналист хочет выразить на бумаге все чувства, являющиеся результатом не только его собственного опыта, но и опыта других людей, которые так же, как и он, решили принять участие в эксперименте Милера и начать новую жизнь на Марсе. Записки показывают, как компьютер захватывает власть над человеком, 
а также то, как люди возвращают себе потерянные свободу и индивидуальность.

Центральной темой романа $M b l$, которая обеспечивает внутреннюю согласованность представляемого мира, организуя его на основе контраста, является тема восстановления личности. Основное место в сюжете занимает образ главного героя и действие, связанное с его психическим развитием. Можно выделить следующие этапы психической эволюции героя: появление сомнений, исследование внешнего мира, отклонение преобладающих законов и заказов.

Знакомство с I-330 становится началом преображения замятинского героя. Увидев девушку I-330, он впервые замечает, что номера разные, мало того - он видит, что не только лохматые руки отличают его от других. Заинтригованный героиней, Д-503 ведет себя непостижимо:

И кроме того - нечто случилось со мной. Правда, это в течение Личного Часа, т. е. в течение времени, специально отведенного для непредвиденных обстоятельств, но все же...

(...) Вдруг - телефон: (...)

- Это я, I-330. Я сейчас залечу за вами, и мы отправимся в Древний Дом. Согласны?

I-330... Эта I меня раздражает, отталкивает - почти пугает. Но именно потому-то я и сказал: да [Замятин 2011, 20].

Сначала поведение I-330 вызывает возражение, даже ненависть у героя: она пьет вино, курит, меняет одежду, сама выбирает себе мужчину. Со временем благодаря отношениям с девушкой конструктор начинает испытывать новые чувства, которые раньше были ему совершенно незнакомы: страсть, ревность. B том-то и ужас, что мне хочется опять этой вчерашней блаженной смерти. В том-то и ужас, что даже теперь, когда логическая функиия проинтегрирована, когда очевидно, что она неявно включает в себя смерть, я все-таки хочу ее губами, руками, грудью, каждым милиметром... [Замятин 2011, 99] - отмечает герой.

Стоит отметить, что в жанре антиутопии интимная жизнь героя вообще является единственным способом проявить свое «я»:

Отсюда - эротичность многих антиутопий, гипертрофированность сексуальной жизни героев либо преувеличенное - на первый взгляд - внимание к воссозданию сексуальных сцен и картин. Телесное оказывается возбудителем духовного, низменное борется с возвышенным, пытаясь пробудить его ото сна [Ланин, online]. 
Замятинский герой приходит к нарушению законов Единого Государства, а в конце концов даже готов сделать для I-330 (вождя революционного движения Мэфи) всё, о чем она ни попросит. Благодаря ей он постепенно начинает понимать, что Единое Государство - его враг ибо человек в нем лишен свободы.

В повести Марсіянскае падарожжа нет героинь, так как для этой антиутопии не имеют значения ни чувства любви, ни сексуальность. $\mathrm{K}$ переменам главного героя побуждают великое прошлое народа и его традиционные и уникальные ценности. В том, что надо выступить против власти, убеждает журналиста электронщик Степан Коренев, обслуживающий Большой Компьютер. Он не согласен с порядком жизни, который навязывает жителям корабля искусственный интеллект. Последней каплей, переполнившей чашу его разочарования и горечи, стал выбор ему жены. Брак без любви вызывает протест у героя: Паверие, я нічога благога супроџь той афрыканскай жанчьны не маю. Дь толькі навошта чалавеку розум, калі яго пачнучь адно з адным, бы жылвёлу зводзічь?.. [Гігевіч 1990, 206-207]. Репродукция человека, согласно закону марсианских путешественников - главный результат интимных отношений, потому что стареющее общество должно заботиться о будущем машинного человечества. Именно поэтому компьютер выбирает родителей, которые будут рожать идеальных детей. Когда детям исполняется три года, их помещают в спецшколы, где они воспитываются искусственным интеллектом. Вследствие этого дети не понимают поколения родителей, а в своей жизни слепо подчиняются воле компьютера. Сама же природа противостоит этому и со временем на кораблях перестают рождать детей.

Замятин и Гигевич изобразили мрачную действительность, в которой рухнули ценности традиционной гуманистической культуры. В финале романа Замятина Д-503 теряет свою индивидуальность: он опять вливается в “мы", становится "нумером" Единого Государства. Подвергнутый Великой Операции, герой избавился от "болезни" - потерял душу и смог рассказать Благодетелю все о бунтовщиках.

Измена Д-503, смерть И-303, разгром восстания и повторное отделение от внешнего, свободного мира раскрывают идейный смысл романа $\mathrm{Mbl}$. Замятин предупреждает, что бездумный научно-технический прогрес ведет к превращению людей в биологических роботов, а далее - к деградации самого человечества.

При этом, хотя на первый взгляд, тоталитарный режим победил, нарушение закона номером Д-503 имело свои последствия. Ведь строитель Интеграла под влиянием эмоций дал О-90 желанного ребенка 
и помог ей сбежать из Единственного Государства. Благодаря этому финал романа носит открытый характер: высказывание I-330 дает надежду, что дитя Д-503 родится и вырастет свободным: Вчера вечером пришла ко мне с твоей запиской... Я знаю - я все знаю: молчи. Но ведь ребенок - твой? И я ее отправила - она уже там, за стеною. Она будет жить... [Замятин 2011, 146].

Бунтовщики из повести Гигевича обрекли себя на небытие. Последствием разрушения Большого Компьютера стала их смерть, но их жертва не была напрастной. В финале повести писатель показывает, что они смогли сберечь свое человеческое достоинство:

Апошнімі намаганнямі я дапісваю нашу сумную трагічную гісторыю, якая у у каторы раз сведчыць пра адзінае: чалавека скарыць нельга. Яго можна адурачыць на час, як адурачылі некалі і нас, з яго можна здзекавацца гадамі, але потым, нарэшце, надыходзіць той час, калі спакутаваны чалавек кідае выклік уладарам і перастае баяцца нават смерці [Гігевіч 1990, 216].

Герою Гигевича свойственно экзистенциальное видение мира, которое предполагает, что очутившись в “пограничной ситуации", представ перед лицом смерти, выбором "быть или не быть", герои борются до конца за свое право остаться человеком. Настоящая ценность жизни, необратимость времени открываются перед героями повести Марсіянскае падарожжа, когда изменить внешние фатальные обстоятельства уже невозможно. Однако, реализуя свое право выбора, они руководствуются духовным принципом, который предполагает, что человека можно уничтожить, но не победить. Таким образом, для Гигевича важным является экзистенциальный, морально-этический потенциал антиутопии.

Типологическое сопоставление романа $\mathrm{Mbl}$ Замятина и повести Марсіянскае падарожжа Гигевича позволяет выделить сходства и различия их антиутопий. Центральным конфликтом обоих произведений является столкновение между силами, утверждающими антиутопические структуры, и силами, противостоящими им. В романе Замятина и повести Гигевича содержится предупреждение об опасности утраты индивидуальности, о возможном трагическом следствии развития реальных жизненных тенденций. Сходная проблематика, тип повествования, реминисцентная насыщеность - основные общие признаки исследуемых произведений. Главное же отличие касается героя и его психологической эволюции. В классической антиутопии, как у Замятина, герой из-за появления в его жизни человека-идеолога готов уничтожить 
мир, в который верил. В свою очередь, глобальные угрозы, с которыми столкнулось человечество в конце XX века, подтолкнули писателей, в том числе и Гигевича, к созданию нового типа героя, способного и готового на противостояние власти, даже ценой собственной жизни.

\section{Литература}

Andraûk S. A., 2015, Vasil' Gigevič, [u:] Gistoryâ belaruskaj litaratury XX stagoddzâ, t. 4, kn. 3, Minsk, s. 806-835. [Андраюк C. А., 2015, Васіль Гігевіч, [у:] Гісторыя беларускай літаратурь ХХ стагоддзя, т. 4, кн. 3, Мінск, c. $806-835$.]

Denisov S. F., Denisova L. V., 2017, Hudožestvennye antiutopii: tipologiâ i filosofsko-antropologičeskie smysly, "Vestnik Čelabinskogo gosudarstvennogo universiteta", № 7 (403), s. 19-26. [Денисов С. Ф., Денисова Л. В., 2017, Художественные антиутопии: типология и философско-антропологические смыслль, "Вестник Челабинского государственного университета", № 7 (403), с. 19-26], [online], https://cyberleninka.ru/article/n/hudo zhestvennye-antiutopii-tipologiya-i-filosofsko-antropologicheskie-smysly/vie wer, [15.12.2019].

Dudzìnskaâ D. İ.-T., 2009, Da prablemy žanru antyutopì ǔ belaruskaj litaratury, [u:] Vyâǔlenča-mastackîa, arganizacyjnyâ ì idèalagičnyâa prablemysučasnaj belaruskaj litaratury ǔ âe suvâzâh z gramadskimi praktykami. Matèryâly Rèspublikanskaj navukova-tèarètyčnaj kanfkrèncyì (Mìnsk, 19-20 mâ̂ 2009 goda), rèdkal. M. A. Tyčyna ì ìň., Mìnsk, s. 90-96. [Дудзінская Д. І.-Т., 2009, Да праблемы жанру антыутопіi ў беларускай літаратурьl, [y:] Bbяўленча-мастачкія, арганізачьйныля $і$ ідэалагічныя праблемь сучаснай беларускай літаратуры ў яе сувязях з грамадскімі практыкамі. Матэрылялы Рэспубліканскай навукова-тэарэтычнай канфкрэнцыі (Мінск, 19-20 мая 2009 года), рэдкал. М. А. Тычына і інш., Мінск, с. 90-96.]

Gìgevič V., 1990, Marsiânskae padarožža. Raman, apovescì, Mìnsk. [Гігевіч В., 1990, Марсіянскае падарожжа. Раман, аповесиі, Мінск.]

Golubovič N. V., M. A. Bulgakov i sovremennâ̂ belorusskâ̂ proza [Голубович Н. В., М. А. Булгаков и современная белорусская проза], [online], https://lib.vsu.by/jspui/bitstream/123456789/5078/1/t11pub123.pdf, [30.04.2020].

Golubovič N. V., Povesti M. Bulgakova "Rokovye âjca", "Sobače serdce" $i$ V. Gigeviča "Korabl", "Pabaki": $k$ voprosu o žanrovyh modifikaciâh social'noj fantastiki [Голубович Н. В., Повести М. Булгакова "Роковые яйча", "Собачье сердие" и В. Гигевича "Корабль", "Пабаки": к вопросу о жанровых модификаииях сочиальной фантастики], [online], https://lib.vsu.by/jspui/ bitstream/123456789/9959/1/179-181.pdf, [30.04.2020]. 
Ždanov Û. A., Antiutopiâ XX veka: ètapy bol'šogoputi [Жданов Ю. А., Антиутопия XX века: этапьи большого пути], [online], http://lib.sevsu.ru:8080/ xmlui/bitstream/handle/123456789/102/Fhilolog.76.2005.123-134.pdf?sequ ence $=1 \&$ isAllowed $=\mathrm{y}$, [05.11.2019].

Zamâtin E., 2011, My. Roman, povest', rasskazy, literaturnâ̂ publicistika, Minsk. [Замятин Е., 2011, Мыь. Роман, повесть, рассказы, литературная публицистика, Минск.]

Izvekova I., Антиутопиа̂: перспективы развитиаิ итрансформации з̆анра в современной литературе [Извекова И., Антиутопия: перспективы развития и трансформации жанра в современной литературе], [online], http://www.ea.donntu.org:8080/bitstream/123456789/31916/1/Izvyekova2 01604.pdf, [30.04.2020].

Lanin B., Anatomiâ literaturnoj antiutopii [Ланин Б., Анатомия литературной антиутопии], [online], http://ecsocman.hse.ru/data/120/386/1217/017_LA NIN.pdf, [01.12.2019].

Navrozov L., Zamâtin i Oruèll: 2h2=4? [Наврозов Л., Замятин и Оруэлл: 2x2=4?], [online], http://www.orwell.ru/a_life/navrozov/russian/r_zio, [27.10. 2018].

Smirnov A. U.., 2005, Antiutopiâ v paradigme sovremennogo literaturovedeniâ, "Vesnì BDU" ser. 4, № 3, s. 32-36. [Смирнов А. Ю., Антиутопия в парадигме современного литературоведения, "Веснік БДУ" 2005, сер. 4, № 3 , c. $32-36$.]

Šiškina S. G., Literaturnâa antiutopiâ: $k$ voprosuo granicah žanra [Шишкина С. Г., Литературная антиутопия: $\kappa$ вопросу о граничах жанра], [online], https://www.isuct.ru/e-publ/vgf/sites/ru.e-publ.vgf/files/2007/vgf-2007-02199.pdf, [10.12.2019].

Tyčko G. K., 2010, Antyǔtopiâ ̌̌ tvorčasci Vasilâ Gigeviča, [y:] G. K. Tyčko, Belaruskâ̂ litaratura XIX-XX stagoddzâŭ: čas i asoby, Mìnsk. [Тычко Г. К., 2010, Антыйтопія ў творчасчі Васіля Гігевіча, [у:] Г. К. Тычко, Беларуская літаратура XIX-XX стагоддзяў: час $і$ асобь, Мінск], [online], https://studfile.net/preview/5792697/page:22/, [10.12.2019].

Stownik rodzajów i gatunków literackich, pod red. G. Gazdy, Warszawa 2012.

Wojtczak D., Siódmy krag piekta. Antyutopia w literaturze i filmie, Poznań 1994.

\section{ANTI-UTOPIAN WORKS BY YEVGENY ZAMYATIN AND VASIL HIHIEVICZ: THE PROBLEM OF SIMILARITIES AND DIFFERENCES}

ABSTRACT

Key words: anti-utopia, We novel, Martian Journey story, warning

The article analyses Zamyatin's novel We (1921) and Hihiewicz's story Martian Journey (1990). Zamyatin is considered to be the father of the anti-utopian genre, and We became a source of inspiration for many writers, including George Orwell 
and Aldous Huxley. Hihiewicz, in his works, repeatedly portrayed the society of the future, completely subordinated to the system of state power. Similar issues and kinds of narration are the main features that link both analysed works. However, the transformation of Zamyatin's protagonist is only temporary, as a consequence of which he returns to the initial situation, to the life absolutely subordinated to the state power. On the other hand, Hihiewicz's protagonists solve existential problems by choosing between life in captivity and death. 